\title{
Effects of shook swarm and supplementary feeding on oxytetracycline levels in honey extracted from treated colonies ${ }^{1}$
}

\author{
Helen M. THOMPSON ${ }^{\mathrm{a} *}$, Ruth J. WAITE ${ }^{\mathrm{a}}$, Selwyn WILKINS ${ }^{\mathrm{a}}$, Michael A. BROWN ${ }^{\mathrm{a}}$, \\ Tim BIGWOOD ${ }^{\mathrm{b}}$, Marvin SHAW ${ }^{\mathrm{b}}$, Christopher RIDGWAY ${ }^{\mathrm{b}}$, Matthew SHARMAN ${ }^{\mathrm{b}}$ \\ a National Bee Unit, Central Science Laboratory, Sand Hutton, York, YO41 1LZ, UK \\ b Veterinary Drug Residue Team, Central Science Laboratory, Sand Hutton, York, YO41 1LZ, UK
}

Received 4 January 2005 - revised 21 June 2005 - accepted 21 June 2005

\begin{abstract}
This study aimed to assess oxytetracycline (OTC) residue levels in honey up to 12 weeks after treatment of honeybee colonies with two methods of treatment (shook swarm and large volume feeding post-treatment) and two methods of application (in liquid sucrose and in powdered icing sugar). Samples of honey were extracted up to 12 weeks after treatment and analysed by HPLC following metal chelation. Residues in the honey collected from the treated colonies 56 days after treatment (the current withdrawal period) were in excess of the LOQ $\left(0.05 \mathrm{mg} \mathrm{kg}^{-1}\right)$. These data suggest a withdrawal period of up to 16 weeks is required for colonies treated with OTC in liquid sucrose and up to 18 weeks is required for those colonies treated in icing sugar. The data from these experiments have been used as the basis of a recommendation that shook swarm without OTC treatment is the preferred method of EFB control in the UK and if OTC is used then the withdrawal period is extended to 6 months after application.
\end{abstract}

Apis mellifera / oxytetracycline / residue / European foulbrood / antibiotic / withdrawal period

\section{INTRODUCTION}

All statutory treatments for European foulbrood (EFB) in England and Wales are undertaken by Appointed Bee Inspectors as part of the Bee Health Programme. Oxytetracycline (OTC) has been used since 1967; however, in Europe there is no maximum residue limit (MRL) currently set for this antibiotic in honey, and therefore there is a zero tolerance limit after treatment. The use of OTC for the treatment of EFB in the UK is considered by the authorities as within the cascade system for veterinary medicines under minor uses, minor species (EMEA, 2004). Current analytical methods used in the UK for the analysis of tetracyclines in food permit the reliable quantification of these drugs at concentrations of $0.05 \mathrm{mg} \mathrm{kg}^{-1}$ or lower. The current method used for oxytetracycline treatment of EFB in colonies in England and Wales is to apply a suspension of $1 \mathrm{~g}$ OTC in sugar syrup (64\% sucrose). However, antibiotic residue data for colonies up to 12 weeks after this treatment (Thompson et al., 2005) showed that this resulted in levels above both the $0.3 \mathrm{mg} \mathrm{kg}^{-1}$ MRL set for Canada and Australia (CHC, 2003; McKee, 2003) and the $0.05 \mathrm{mg} \mathrm{kg}^{-1}$ limit of quantification. There is an increasing programme of screening of honey for antibiotic residues required under European legislation and administered in the UK by the Veterinary Medicines Directorate (VMD). It is possible that current methods of authorised colony treatment may result in detectable residues

* Corresponding author: H.Thompson@csl.gov.uk

1 Manuscript editor: Jean Noël Tasei 
of OTC in honey sold by beekeepers. This study aimed to generate data on the residue levels in extracted honey over time after alternative methods of treatment, to establish which method resulted in the lowest residues of OTC. There is increasing interest in the UK in alternative methods of treatment that reduce reliance on antibiotics, therefore a study has been running for several years on the use of shook swarm treatment (Waite et al., 2003). This involves removal of brood combs and replacement with foundation and, currently, supplementary feeding of the adult bees with OTC in sugar syrup (although ultimately the aim is to move away from any antibiotic use). Therefore, the methods evaluated in the current study were shook swarm treatment with OTC (as the formulation Terramycin) in either sucrose solution or powdered sugar, and the OTC administration in a small volume of sucrose solution or powdered sugar without shook swarm treatment but followed by supplementary feeding with sucrose in an attempt to dilute any OTC residues through feeding and establish an appropriate withdrawal period.

\section{MATERIALS AND METHODS}

Oxytetracycline for colony dosing was obtained as the formulation Terramycin $(5.5 \% \mathrm{w} / \mathrm{w}$ oxytetracycline, equivalent to $1 \mathrm{~g}$ active ingredient, Pfizer Ltd) from the Veterinary Laboratory Agency (VLA), Weybridge, Surrey, UK. Oxytetracycline $\mathrm{HCl}$ for residue analysis was obtained from Sigma Ltd. All solvents were of HPLC grade and other chemicals of analytical reagent grade. Chelating sepharose (Fast Flow; in $20 \%$ ethanol) was obtained from Pharmacia.

The study was carried out in June-October 2003. Standardised colonies of UK type honeybees (Apis mellifera L.), maintained and owned by the Central Science Laboratory (CSL), were used in this study. Test colonies were housed in full-size wooden Smith hives and were allowed free flight during the study. At the start of the trial these colonies showed no clinical signs of European or American foulbrood, sacbrood or baldbrood and had only a low incidence of the minor brood disease chalkbrood. The test colonies were transferred to the experimental site at Sand Hutton, placed at least $20 \mathrm{~m}$ apart to minimise drifting and randomly assigned to treatments. Six colonies were used per treatment.

\subsection{Shook swarm pre-treatment}

One group of six colonies (five in double brood chambers, one single brood chamber) were shaken onto foundation and treated with $1 \mathrm{~g}$ OTC in powder (formulation mixed 1:2 by weight in icing sugar then sprinkled onto the top bars of the frames in the upper chamber), then fed four litres sugar syrup. The second group of six colonies (four in double brood chambers, two single brood chambers) were shaken and fed $1 \mathrm{~g}$ OTC formulation dissolved in four litres sugar syrup $(50 \% \mathrm{w} / \mathrm{v})$.

\subsection{Post-treatment feeding}

As shook swarm treatment in the UK is limited to the periods in which the colonies have sufficient time to rebuild prior to the end of the season, one treatment group of six colonies (all double brood chamber) was dosed with a suspension of $1 \mathrm{~g}$ OTC in $200-250 \mathrm{~mL}$ aqueous sucrose solution $(64 \% \mathrm{w} / \mathrm{v})$ poured into empty brood combs in the upper brood chamber. The other treatment group of six colonies (all double brood chamber) was dosed with $1 \mathrm{~g}$ OTC (formulation mixed 1:2 in powdered icing sugar) and sprinkled over the top bars of the brood frames in the upper brood chamber. All the colonies were then fed with four litres sugar syrup and a super containing empty drawn combs was added.

\subsection{Residue analysis}

\subsubsection{Sampling}

One, three, six, seven/eight, and ten/twelve weeks after treatment, mixed samples of honey/nectar and wax were taken from combs in the treated colonies. Samples were taken from the super (present from the start of the study) or, if there was insufficient honey in the super, from frames in the brood chamber. Approximately $100 \mathrm{~g}$ material was taken from each colony. The honey/nectar samples were collected by filtering through cloth into a clean glass jar labelled with the study number, colony, source (brood or super), treatment, date and initials of person collecting the sample. All residue samples were stored at approximately $-20{ }^{\circ} \mathrm{C}$ before being analysed.

\subsubsection{HPLC analysis}

Chemical analysis was performed using an ISO 17025 accredited HPLC procedure currently employed for monitoring oxytetracycline levels in UK and imported honeys as part of the VMD Non-Statutory Surveillance Programme (VMD, 2003). Stock standard solutions were prepared at $1 \mathrm{mg} \mathrm{mL}^{-1} \mathrm{OTC}$ in methanol and were stable for at least 1 month at $+4{ }^{\circ} \mathrm{C}$. Intermediate and working solutions were prepared daily typically at $10 \mu \mathrm{g} \mathrm{mL}^{-1}$ and $1 \mu \mathrm{g} \mathrm{mL}^{-1}$ OTC respectively by diluting stock standard with water. The mobile phase was prepared by mixing 
2 parts acetonitrile with 8 parts $0.01 \mathrm{M}$ oxalic acid and passing through a $0.45 \mu \mathrm{m}$ filter assisted by vacuum.

Honey ( $5 \mathrm{~g}$ ) was weighed into a Falcon tube. Fortified samples were prepared by the addition of appropriate amounts of spiking solution to known negatives. $0.05 \mathrm{M}$ succinate buffer $\mathrm{pH} 4.0$ (prepared by adding $37.2 \mathrm{~g}$ EDTA disodium salt to $0.05 \mathrm{M}$ succinate solution and adjusting to $\mathrm{pH} 4.0$ ) was added, the mixture was vortex-mixed and shaken, then the supernatant removed and the residue was reextracted with further succinate buffer. The first and second supernatant samples were loaded onto the sepharose column under vacuum (prepared by adding $5 \mathrm{~mL}$ sepharose suspension to a $65 \mathrm{~mm} \times 13 \mathrm{~mm}$ i.d. SPE reservoir and placing under vacuum until most of the excess liquid was drained off then washed with water, $5 \%$ copper sulphate solution and then followed by water). The column was washed with water, methanol and water and eluted with EDTA - succinate buffer. The eluate was passed through an Oasis HLB cartridge (Waters; previously conditioned with $2 \mathrm{~mL}$ methanol followed by $2 \mathrm{~mL}$ water). The cartridge was washed with $2 \mathrm{~mL}$ methanol:water (10:90) and dried under vacuum for $1 \mathrm{~min}$. The cartridge was eluted with $10 \mathrm{~mL}$ ethyl acetate into a test tube containing $100 \mu \mathrm{L}$ of ethane diol:methanol (10:90) and the eluate evaporated to dryness at a temperature not exceeding $40^{\circ} \mathrm{C}$ under nitrogen. The residue was redissolved in $500 \mu \mathrm{L}$ water with vortexing and sonication. The resulting final extract was diluted 10 -fold with water for analysis by HPLC. HPLC was performed on $500 \mu \mathrm{L}$ diluted extract.

HPLC equipment comprised a Gilson 306 pump with manometric module, Gilson 231 autosampler with 402 dilutor and $100 \mu \mathrm{L}$ sample loop and a Gilson UV/VIS-151 detector with PE 900 Series interface. Data was acquired using PE Nelson Turbochrom software. The analytical column consisted of two joined $100 \mathrm{~mm} \times 3 \mathrm{~mm}$ i.d. Varian ChromSpher 5 C8 columns. Separation was achieved under isocratic conditions using a flow rate of $0.4 \mathrm{~mL} \mathrm{~min}-1$ and detection was by UV monitoring at $350 \mathrm{~nm}$. The limit of quantification was $0.05 \mathrm{mg} \mathrm{kg}^{-1}$ (i.e. one half of the lowest EU MRL for oxytetracycline).

\section{RESULTS}

\subsection{Shook swarm pre-treatment}

Residue analysis information is summarised in Figure 1. Samples could only be taken from the brood chamber due to the low levels of stores present in all the colonies during the study despite feeding. Three colonies treated with OTC in liquid failed to provide sufficient
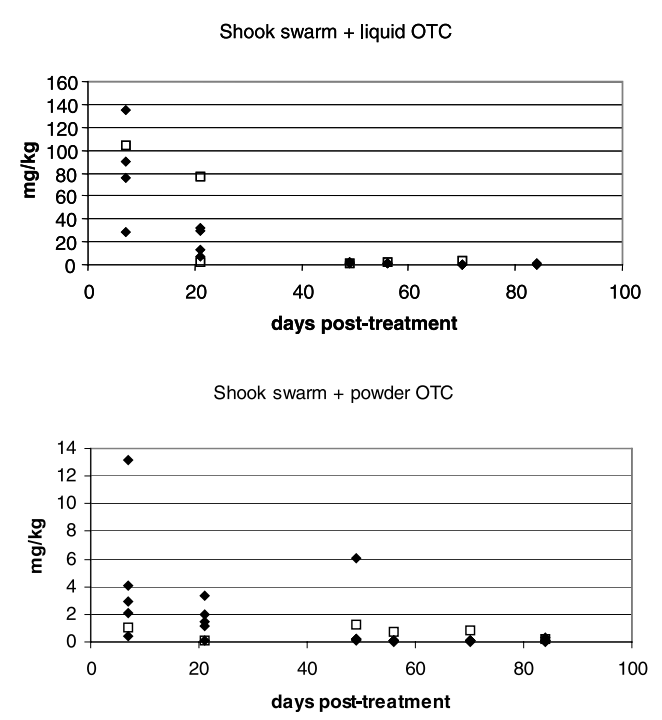

Figure 1. Oxytetracycline residue levels in shook swarm treated colonies. Data points are shown for individual colonies at each sampling point (note the 10 fold difference in the axis between liquid and powder treatments). Single brood box colonies are shown as open symbols, double brood chamber as solid symbols.

samples for analysis for the full 12 weeks of the study. Seven days after treatment, the mean residue levels in the shook swarm with OTC in liquid treated colonies was $86 \mathrm{mg} \mathrm{kg}^{-1}$ (range $28-$ $135 \mathrm{mg} \mathrm{kg}^{-1}$ ) and in the shook swarm with OTC in powder treated colonies was $3.9 \mathrm{mg} \mathrm{kg}^{-1}$ (range $1-13 \mathrm{mg} \mathrm{kg}^{-1}$ ). By 49 days after treatment, the residue levels in the liquid treated colonies had declined to a mean of $1.4 \mathrm{mg} \mathrm{kg}^{-1}$ (range $0.7-2.8 \mathrm{mg} \mathrm{kg}^{-1}$ ), and in the powder treated colonies to $0.21 \mathrm{mg} \mathrm{kg}^{-1}$ (range $<0.05-$ $0.7 \mathrm{mg} \mathrm{kg}^{-1}$ ). By 84 days after treatment the residue levels were a mean of $0.25 \mathrm{mg} \mathrm{kg}^{-1}$ (range $<0.05-0.7 \mathrm{mg} \mathrm{kg}^{-1}$ ) in the OTC in liquid treated colonies and $0.13 \mathrm{mg} \mathrm{kg}^{-1}$ (range < $0.05-0.3 \mathrm{mg} \mathrm{kg}^{-1}$ ) in the OTC in powder treated colonies. The powder treatment was visible on the top bars of the brood frames throughout the course of the study and the high level of $6 \mathrm{mg} \mathrm{kg}^{-1}$ in one colony at the end of the study suggests localised "hot spots" of residues.

\subsection{Post-treatment feeding}

Residue analysis information is summarised in Figure 2 (one colony treated with the liquid 
preparation died out immediately post-treatment although the cause could not be identified). Samples were taken from the super or upper brood chamber depending on the availability of stored uncapped honey. Seven days after treatment, the mean residue level in OTC in liquid treated colonies was $20 \mathrm{mg} \mathrm{kg}^{-1}$ (range $0.1-81 \mathrm{mg} \mathrm{kg}^{-1}$ ) and in the OTC in powder treated colonies was $3.4 \mathrm{mg} \mathrm{kg}^{-1}$ (range $\left.0.8-12 \mathrm{mg} \mathrm{kg}^{-1}\right)$. By 56 days after treatment the residue levels in the liquid treated colonies had declined to a mean of $1.5 \mathrm{mg} \mathrm{kg}^{-1}$ (range $0.07-$ $3 \mathrm{mg} \mathrm{kg}^{-1}$ ) and in the powder treated colonies to $0.7 \mathrm{mg} \mathrm{kg}^{-1}$ (range $0.09-1.8 \mathrm{mg} \mathrm{kg}^{-1}$ ). Powder was visible on the top bars of the brood frames throughout the course of the study.

Residues in the honey collected from the treated colonies 56 days after treatment were in excess of the LOQ $\left(0.05 \mathrm{mg} \mathrm{kg}^{-1}\right)$ (Tab. I) and residue decay curves of the course of the study are shown in Figure 3 and compared with those of the standard treatment method previously reported (Thompson et al., 2005). As the decline in residues is likely to be first order kinetics, the equations for the decline in residues for OTC were determined for each of the application methods using plots of $\ln$ (mean concentration) vs. time (days). The data over the period of the trial gave estimated half-lives and times to decline to less than the LOQ of $0.05 \mathrm{mg} \mathrm{kg}^{-1}$ shown in Table II.

\section{DISCUSSION}

The half-lives shown in Table II compare with a calculated half life of unformulated OTC
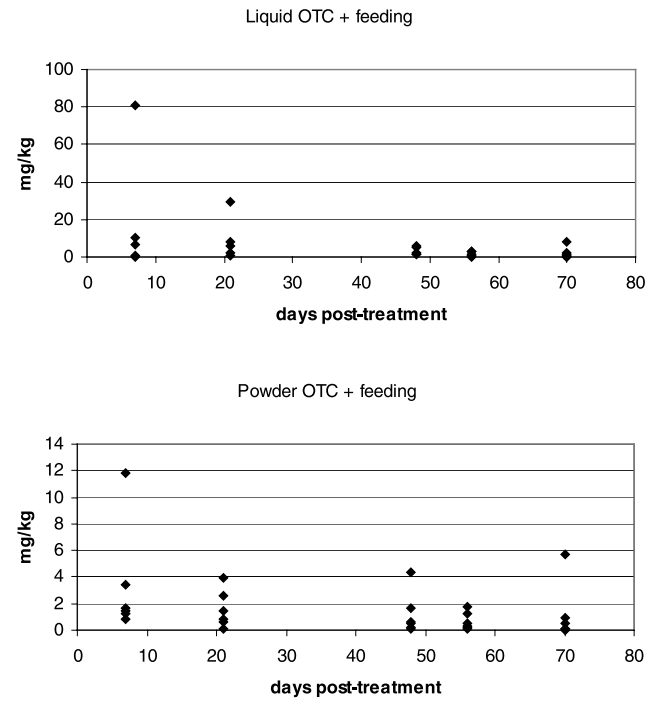

Figure 2. Oxytetracycline residue levels in colonies provided with a supplementary sucrose feed after OTC treatment, data points are shown for individual colonies at each sampling point. All colonies were double brood chamber.

at $34{ }^{\circ} \mathrm{C}$ in the dark in highly purified sucrose is between 7.6 days (Kochansky et al., 1999) and 9 days (CSL NBU, unpublished data), and its half-life in water at $34{ }^{\circ} \mathrm{C}$ is 2 days (Gilliam and Argauer, 1981). Oxytetracycline residues in honey have been reported to decline to below the limit of detection over an 8-week period in vitro (Gilliam et al., 1979; Argauer and Moats, 1991; Matsuka and Nakamura, 1990). The time to decline to residues below the limits is a function of both the half-life and the initial residue.

Table I. Comparison of oxytetracycline residue levels in honey extracted from colonies 8 weeks after treatment using a variety of administration methods.

\begin{tabular}{lcc}
\hline OTC application method & Mean residue & Range \\
\hline 200-250 mL liquid sucrose & \\
Icing sugar powder $^{1}$ & $3.7 \mathrm{mg} \mathrm{kg}^{-1}$ & $0.6-11 \mathrm{mg} \mathrm{kg}^{-1}$ \\
Shook swarm + fed in 4 L liquid sucrose & $0.45 \mathrm{mg} \mathrm{kg}^{-1}$ & $0.3-0.6 \mathrm{mg} \mathrm{kg}^{-1}$ \\
Shook swarm + icing sugar powder & $1.4 \mathrm{mg} \mathrm{kg}^{-1}$ & $0.7-2.8 \mathrm{mg} \mathrm{kg}^{-1}$ \\
200-250 mL liquid sucrose + 4 L sucrose feed & $0.21 \mathrm{mg} \mathrm{kg}^{-1}$ & $<0.05-0.7 \mathrm{mg} \mathrm{kg}^{-1}$ \\
Icing sugar powder + 4 L sucrose feed & $1.5 \mathrm{mg} \mathrm{kg}^{-1}$ & $0.07-3 \mathrm{mg} \mathrm{kg}^{-1}$ \\
\hline
\end{tabular}

${ }^{1}$ Data from Thompson et al. (2005). 


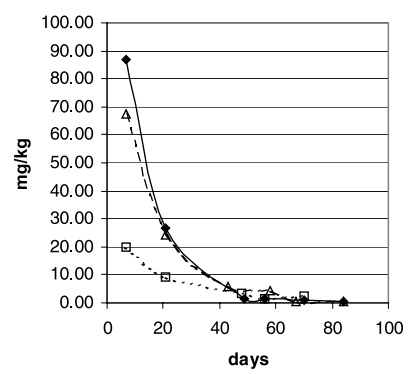

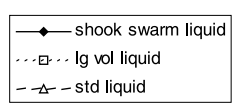

(A1)
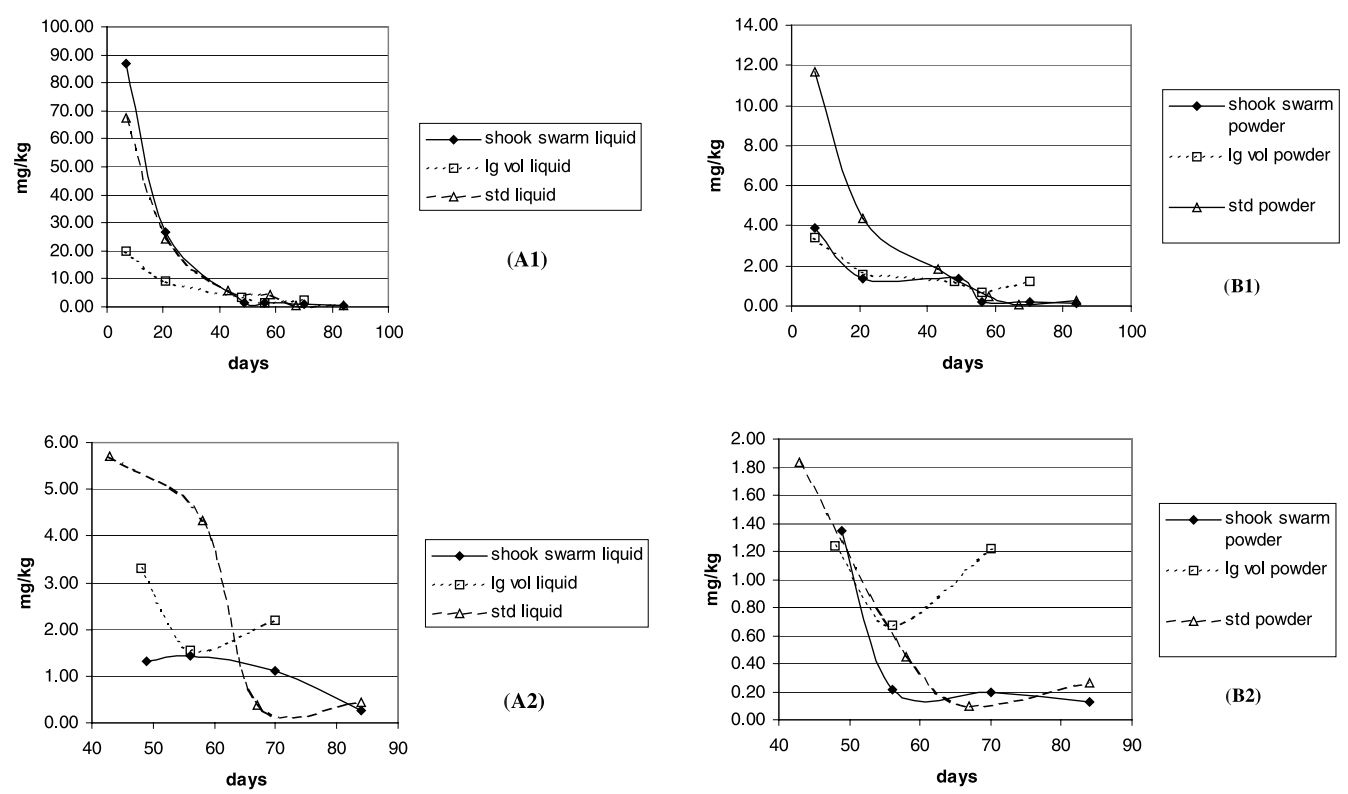

Figure 3. Oxytetracycline residue levels in samples taken from colonies treated with (A) OTC in liquid (shook swarm, fed supplementary sucrose (large volume liquid), and results for standard liquid treatment method ( $1 \mathrm{~g}$ OTC ai in $250 \mathrm{~mL}$ and no supplementary feeding) from Thompson et al., 2005), (A1 for the full duration of the study, A2 with expanded scale from day 42) and with (B) OTC in powder (shook swarm, fed supplementary sucrose, and results for powder treatment $(1 \mathrm{~g} \mathrm{OTC}$ ai in powder with no supplementary feeding) from Thompson et al., 2005) (B1 for the full duration of the study, B2 with expanded scale from day 42). Mean residue levels are shown.

Table II. Estimated half life of OTC residues and time to decline to the LOQ $\left(0.05 \mathrm{mg} \mathrm{kg}^{-1}\right)$ and to $0.3 \mathrm{mg} \mathrm{kg}^{-1}$ (MRL for honey in Australia and Canada) according to application method.

\begin{tabular}{|c|c|c|c|c|}
\hline $\begin{array}{l}\text { OTC application } \\
\text { method }\end{array}$ & $\begin{array}{l}\text { Correlation coefficient ln } \\
\text { (concentration) vs. time }\end{array}$ & $\begin{array}{l}\text { Half life } \\
\text { (days) }\end{array}$ & $\begin{array}{l}\text { Time to reach } 0.05 \mathrm{mg} \mathrm{kg}^{-1} \\
\text { (weeks) }\end{array}$ & $\begin{array}{l}\text { Time to reach } 0.30 \mathrm{mg} \mathrm{kg}^{-1} \\
\text { (weeks) }\end{array}$ \\
\hline $\begin{array}{l}200-250 \mathrm{~mL} \text { liquid } \\
\text { sucrose }^{1}\end{array}$ & -0.96 & 13 & 16 & 13 \\
\hline Icing sugar powder ${ }^{1}$ & -0.93 & 11 & 14 & 10 \\
\hline $\begin{array}{l}\text { Shook swarm }+ \text { fed } \\
\text { in } 4 \mathrm{~L} \text { liquid sucrose }\end{array}$ & -0.98 & 9 & 15 & 11 \\
\hline $\begin{array}{l}\text { Shook swarm }+ \\
\text { icing sugar powder }\end{array}$ & -0.93 & 15 & 15 & 9 \\
\hline $\begin{array}{l}200-250 \mathrm{~mL} \text { liquid } \\
\text { sucrose }+4 \mathrm{~L} \\
\text { sucrose feed }\end{array}$ & -0.95 & 20 & 22 & 16 \\
\hline $\begin{array}{l}\text { Icing sugar powder } \\
+4 \mathrm{~L} \text { sucrose feed }\end{array}$ & -0.80 & 44 & 32 & 18 \\
\hline
\end{tabular}

${ }^{1}$ Data from Thompson et al. (2005). 
Thus, although the initial residues when OTC is applied in powder are lower than when applied in liquid, the half-life within the colony is longer. The observation of powder in the colonies throughout the course of the study suggested that the bees were not attracted to it as a food source. Based on this, and data from the previous study investigating standard treatment with OTC in $200-250 \mathrm{~mL}$ sucrose or in powdered sugar, the withdrawal period required for residues to fall below the LOQ of $0.05 \mathrm{mg} \cdot \mathrm{kg}^{-1}$ is 15 weeks following shook swarm treatment and 16 weeks using the standard method with no supplementary feeding (Tab. II). Supplementary feeding increased the required withdrawal period to 22 weeks. The extrapolation for the values beyond the analysed data have to be interpreted with extreme caution, since there is no data to check that the exponential decay models holds after the 12 weeks observed.

In addition, the data were analysed to determine the time to decay to below the $0.3 \mathrm{mg} \mathrm{kg}^{-1}$ residue levels used as an MRL in Canada and Australia (CHC 2003; McKee, 2003) (Tab. II). As before, since these are calculated from the simple linear regression, they should be interpreted with caution. However, these data suggest a withdrawal period of up to 16 weeks is required for colonies treated with OTC in liquid sucrose and up to 18 weeks is required for those colonies treated with OTC in icing sugar to ensure residues are below the $0.3 \mathrm{mg} \mathrm{kg}^{-1}$ MRL. The data from these experiments have been used as the basis of a recommendation that shook swarm without OTC treatment is the preferred method of EFB control in the UK and if OTC is used then the withdrawal period is extended to 6 months after application.

\section{ACKNOWLEDGEMENTS}

This work was funded by Horticulture and Potatoes Division, Defra (Project HH0825SHB).

Résumé - Effets de l'essaim artificiel et du nourrissement spéculatif sur les niveaux d'oxytétracycline dans le miel extrait de ces colonies. L'étude vise à estimer les niveaux de résidus d'oxytétracycline (OTC) dans le miel jusqu'à 12 semaines après le traitement des colonies d'abeilles (Apis mellifera L.) en fonction de deux méthodes de traitement (essaim artificiel et nourrissement spéculatif post traitement) et deux méthodes d'administration (sous forme liquide dans du saccharose ou pulvérulente dans du sucre glace). Dans un premier groupe, six essaims artificiels ont été constitués et traités avec $1 \mathrm{~g}$ d'OTC sous forme de poudre, puis nourris avec $4 \mathrm{~L}$ de sirop de sucre. Les six essaims artificiels du second groupe ont reçu $1 \mathrm{~g}$ d'OTC dissout dans $4 \mathrm{~L}$ de sirop de sucre (50\% poids/vol.). Comme en Grande-Bretagne la méthode de l'essaim artificiel est limitée aux périodes où les colonies ont suffisamment de temps pour se reconstruire avant la fin de la saison, le traitement de l'un des groupes a consisté en une suspension d' $1 \mathrm{~g}$ d'OTC dans 200-250 mL de solution aqueuse de saccharose (64\% poids/vol) versée dans les cadres de couvain vides dans la partie haute de la chambre à couvain. Le traitement de l'autre groupe a consisté en $1 \mathrm{~g}$ d'OTC (formulation mixte $1 / 2$ dans du sucre glace pulvérulent) vaporisé sur les têtes des cadres de couvain. Toutes les colonies ont ensuite reçu $4 \mathrm{~L}$ de sirop de sucre en nourrissement. Des échantillons de miel/nectar ont été prélevés dans ces cadres une, trois, six, sept/huit et dix/douze semaines après le traitement. L'analyse chimique a été faite selon une procédure HPLC accréditée ISO 17025 et couramment employée pour suivre les taux d'oxytetracycline dans les miels de Grande Bretagne et les miels importés dans le cadre du Programme VMD de Surveillance Non-Réglementaire (VMD, 2003). La limite de dosage (LOQ) était de $0,05 \mathrm{mg} \mathrm{kg}^{-1}$ (i.e. la moitié de la plus petite limite maximum de résidu de l'UE pour l'oxytétracycline). Les résidus dans le miel récolté $56 \mathrm{j}$ après le traitement dépassaient la LOQ $0.05 \mathrm{mg}$ (Figs. 1 et 2 , Tab. I) et les courbes de dégradation des résidus sont présentées dans la figure 3 et comparées avec celles de la méthode de traitement standard précédemment utilisée (Thompson et al., 2005). Comme la baisse des résidus a vraisemblablement une cinétique de premier ordre, les équations de la baisse des résidus d'OTC ont été déterminées pour chaque mode d'administration à l'aide des courbes du logarithme de la concentration moyenne en fonction du temps (j). Les données obtenues ont donné une estimation des demi-vies et des durées nécessaires pour passer sous la LOQ de $0,05 \mathrm{mg} \mathrm{kg}^{-1}$ (Tab. II). Bien que les résidus initiaux soient inférieurs quand l'OTC est administré sous forme de poudre plutôt que sous forme liquide, la demi-vie dans la colonie est plus longue. Ceci confirme une observation faite au cours de l'expérimentation : la poudre est restée visible sur les têtes des cadres de couvain durant toute l'étude, ce qui suggère qu'elle ne constitue pas pour les abeilles une source de nourriture attractive. En se basant là-dessus et sur les données de l'étude précédente faite avec le traitement standard (OTC dans 200-250 mL de saccharose ou dans du sucre en poudre), la période de retrait nécessaire pour que les résidus tombent en-dessous de la LOQ de $0,05 \mathrm{mg} \mathrm{kg}^{-1}$ est de 15 semaines suivant le traitement par essaim artificiel et de 16 semaines si l'on utilise la méthode standard sans nourrissement spéculatif (Tab. II). Le nourrissement spéculatif repousse la période de retrait nécessaire à 22 semaines. 
Apis mellifera / oxytétracycline / résidu / antibiotique / loque européenne / période de retrait

Zusammenfassung - Effekte einer Kunstschwarmerstellung und einer Zusatzfütterung auf die Oxytetracyclin-Gehalte in Honigen behandelter Völker.Ziel dieser Studie war es, die Oxytetracyclin (OTC)-Rückstände in Honigen 12 Wochen nach der Behandlung von Bienenvölkern zu bestimmen. Wir wählten zwei Behandlungsmethoden (Kunstschwarmerstellung und Zusatzfütterung nach der Behandlung) und zwei Applikationsmethoden (OTC in Flüssigzucker und in Puderzucker). Die Erstellung von Kunstschwärmen als Therapiemethode ist in Grossbritannien auf die Periode beschränkt, in der Bienen genügend Zeit verbleibt, um sich bis zum Saisonende wieder aufzubauen. Deshalb wurde bei jeweils sechs Kunstschwärmen in der einen Versuchsgruppe die OTC-Dosis von $1 \mathrm{~g}$ (in 200-250 mL Zuckersirup, $64 \% \mathrm{w} / \mathrm{v}$ ) direkt in die offenen Brutwaben der oberen Brutzarge geschüttet, während bei der zweiten die OTC-Dosis ( $1 \mathrm{~g}$ in einer 1:2 Puderzuckerformulierung) auf die oberen Rahmen der Brutwaben gesiebt wurde. Beide Gruppen erhielten anschliessend eine Zusatzfütterung von 4 L Zuckerlösung (50\% w/v). Honigproben wurden nach einer und dann nach drei, sieben/acht und zehn/ zwölf Wochen aus den behandelten Völkern gezogen. Die chemische Rückstandsanalyse erfolgte entsprechend der ISO 17025-Richtlinie mittels eines HPLC-Verfahrens, das gegenwärtig für die Überwachung von OTC-Gehalten in Honigen als Teil des VMD Non-Statutory Surveillance Programme (VMD, 2003) eingesetzt wird. Die Nachweisgrenze lag bei $0,05 \mathrm{mg} \mathrm{kg}^{-1}$ (d.h. der Hälfte des niedrigsten EU-Werts für Oxytetracycline).

Die Rückstandswerte in Honigen lagen 56 Tage nach der Behandlung noch deutlich über dem Grenzwert (LOQ 0,05 $\mathrm{mg} \mathrm{kg}^{-1}$ ) (Abb. 1 und 2 und Tab. I). Die Abbauraten in dieser Studie (Abb. 3) waren mit denen aus Standardbehandlungsmethoden vergleichbar (Thompson et al., im Druck). Da die Abbaurate einer Kinetik erster Ordnung folgen sollte, wurden die Gleichungen für den Abbau von OTCRückständen für die jeweilige Behandlungsmethode als mittlere Konzentration gegen die Zeit (in Tagen) aufgetragen. Die geschätzten Halbwertszeiten und die Zeiten bis zum Erreichen des Grenzwerts sind in Tabelle II zusammengestellt. Obwohl die anfänglichen Rückstandswerte niedriger waren, wenn OTC in der Puderformulierung verabreicht wurde, verblieb diese länger in der Kolonie als nach der OTCBehandlung in Flüssigzucker. Dies ist in Einklang mit der Beobachtung, dass der Puder während der gesamten Versuchsperiode auf den oberem Rahmen der Brutwaben zu sehen war. Zusammen mit Daten aus einer früheren Studie zeigt dies, dass der Zeitraum bis zum Erreichen des OTC-Grenzwerts in Honigen bei der Kunstschwarmbehandlung bei 15 Wochen lag und bei der Standardbehandlung bei
16 Wochen, wenn keine Zusatzfütterung erfolgte (Tab. II). Die Zusatzfütterung mit Zuckerlösung verlängerte diesen Zeitraum auf 22 Wochen (Tab. II).

Apis mellifera / Oxytetracycline / Rückstände /
Antibiotika / Europäische Faulbrut / Kunstschwarm

\section{REFERENCES}

Argauer R., Moats W. (1991) Degradation of oxytetracycline in honey as measured by fluorescence and liquid chromatographic assays, Apidologie 22, 109-115.

CHC (2003) MRL for oxytetracycline, (http://www. honeycouncil.ca/users/folder.asp?FolderID $=876$ $\& n I D=302$ ) (accessed on 13 October 2005).

EMEA (2004) Position paper regarding availability of products for minor uses and minor species (MUMS) EMEA/CVMP/477/03 (http://www.emea. eu.int/pdfs/vet/swp/047703en.pdf) (accessed on 13 October 2005).

Gilliam M., Argauer R. (1981) Oxytetracycline residues in surplus honey, brood nest honey, and larvae after medication of colonies of honey bees, Apis mellifera, with antibiotic extender patties, sugar dusts and syrup sprays, Environ. Entomol. 10, 479-482.

Gilliam M., Taber S., Argauer R. (1979) Degradation of Terramycin in sugar syrup and honey stored by honeybee colonies, J. Apic. Res. 18, 208-211.

Kochansky J., Knox D., Shimanuki H. (1999) Comparative stability of oxytetracycline and tylosin in sugar syrup, Apidologie 30, 321-326.

Matsuka M., Nakamura J. (1990) Oxytetracycline residues in honey and royal jelly, J. Apic. Res. 29, 112-117.

McKee B. (2003) Prevention of residues in honey: A future perspective, Apiacta 38, 173-177.

Thompson H.M., Waite R.J., Wilkins S., Brown M.A., Bigwood T., Shaw M., Ridgway C., Sharman M. (2005) Effects of European foulbrood treatment regime on oxytetracycline levels in honey extracted from treated honeybee (Apis mellifera) colonies and toxicity to brood, Food Addit. Contam. 26, 573-578.

VMD (2003) Annual Report on Surveillance for Veterinary Residues in Food in the UK, 2003. Veterinary Residue Committee, http://www.vet-residues-committee.gov.uk/ (accessed on 13 October 2005).

Waite R., Brown M., Thompson H. (2003) Controlling European foulbrood with the shook swarm method and oxytetracycline in the UK, Apidologie 34, 569-575. 